\title{
Near-Infrared Aggregation-Induced Emission-Active Probe Enables in situ and Long-Term Tracking of Endogenous $\beta$-Galactosidase Activity
}

\section{OPEN ACCESS}

Edited by:

Tony D. James,

University of Bath, United Kingdom

Reviewed by:

Wenjing Tian

Jilin University, China

Jingzhi Sun,

Zhejiang University, China

*Correspondence:

Zhiqian Guo

guozq@ecust.edu.cn

tThese authors have contributed equally to this work

Specialty section: This article was submitted to

Chemical Biology

a section of the journal

Frontiers in Chemistry

Received: 31 January 2019 Accepted: 09 April 2019

Published: 14 May 2019

Citation:

Fu W, Yan C, Zhang Y, Ma Y, Guo Z and Zhu W-H (2019) Near-Infrared Aggregation-Induced Emission-Active Probe Enables in situ and Long-Term Tracking of Endogenous

$\beta$-Galactosidase Activity.

Front. Chem. 7:291.

doi: 10.3389/fchem.2019.0029

\section{Wei Fu+, Chenxu Yan ${ }^{\dagger}$, Yutao Zhang, Yiyu Ma, Zhiqian Guo* and Wei-Hong Zhu}

State Key Laboratory of Bioreactor Engineering, Shanghai Key Laboratory of Functional Materials Chemistry, School of Chemistry and Molecular Engineering, Institute of Fine Chemicals, East China University of Science and Technology, Shanghai, China

High-fidelity tracking of specific enzyme activities is critical for the early diagnosis of diseases such as cancers. However, most of the available fluorescent probes are difficult to obtain in situ information because of tending to facile diffusion or inevitably suffering from aggregation-caused quenching (ACQ) effect. In this work, we developed an elaborated near-infrared (NIR) aggregation-induced emission (AIE)-active fluorescent probe, which is composed of a hydrophobic 2-(2-hydroxyphenyl) benzothiazole (HBT) moiety for extending into the NIR wavelength, and a hydrophilic $\beta$-galactosidase ( $\beta$-gal) triggered unit for improving miscibility and guaranteeing its non-emission in aqueous media. This probe is virtually activated by $\beta$-gal, and then specific enzymatic turnover would liberate hydrophobic AlE luminogen (AlEgen) QM-HBT-OH. Simultaneously, brightness NIR fluorescent nanoaggregates are in situ generated as a result of the AlE-active process, making on-site the detection of endogenous $\beta$-gal activity in living cells. By virtue of the NIR AlE-active performance of enzyme-catalyzed nanoaggregates, QM-HBT- $\beta$ gal is capable of affording a localizable fluorescence signal and long-term tracking of endogenous $\beta$-gal activity. All results demonstrate that the probe QM-HBT- $\beta$ gal has potential to be a powerful molecular tool to evaluate the biological activity of $\beta$-gal, attaining high-fidelity information in preclinical applications.

Keywords: fluorescent probe, near-infrared, aggregation-induced emission, $\beta$-galactosidase, in situ, long-term tracking

\section{INTRODUCTION}

Specific enzymes play vital roles in a wide range of biological processes. Among them, $\beta$-galactosidase ( $\beta$-gal) is overexpressed in primary ovarian cancers, which has been regarded as an important biomarker for cell senescence and ovarian cancer diagnosis (Dimri et al., 1995; Spergel et al., 2001). In view of this importance, real-time tracking of $\beta$-gal activity has become a powerful tool for accurate disease diagnostics. Recently, fluorescent probes have gained ever-increasing attention owing to its noninvasiveness to tissue and high sensitivity (Sun et al., 2016; Xu K. et al., 2016). However, current strategy for enzyme probes is generally based on fluorophores that are soluble in the cytoplasm (Bhuniya et al., 2014; Li X. et al., 2014; Zhang et al., 2014, 2018; Wang F. et al., 2015; Xu et al., 2015; Makukhin et al., 2016; Wu et al., 2016; Chen X. et al., 2017). These responsive probes 
largely suffer from inaccurate in situ information about biocatalytic activity, because the products of small molecules by enzyme conversion quickly diffuse away from the site of their generation (Kamiya et al., 2011; Yang et al., 2013; Li L. et al., 2014; Yin et al., 2014; Xu Q. et al., 2016; Zhou et al., 2016; Zhu et al., 2016; Wu et al., 2017). These released fluorophores even tend to translocate out of cells, thus making long-term tracking in living subjects difficult (Taylor et al., 2012; Wang et al., 2013; Liu H. W. et al., 2017). On the other hand, it is still far from achieving in situ accurate information, owing to the distorted signal from inevitable aggregation-caused quenching (ACQ) effect (Sun et al., 2014; Wu et al., 2014; Li et al., 2015; Gu et al., 2016; Liu Z. et al., 2017; Qi et al., 2018). Therefore, it is an urgent demand to overcome the dilemma of the released fluorophores between aggregation requirement for diffusionresistant and ACQ effect resulting from aggregation.

With this in mind, we envisioned that near-infrared (NIR) aggregation-induced emission (AIE) probes (Qin et al., 2012; Leung et al., 2013; Mei et al., 2015; Guo et al., 2016; Wang et al., 2016; Yan et al., 2016; Liu L. et al., 2017; Shi et al., 2017; Yang et al., 2017; Zhang F. et al., 2017; Feng and Liu, 2018; Wang Y.-L. et al., 2018; Xie et al., 2018) can provide reliable opportunities to address the aforementioned intractable dilemma. The design of the AIE fluorophores extending into NIR wavelength for decreased autofluorescence and high penetration depth is essentially required for attaching additionally a hydrophobic $\pi$-conjugated bridge (Guo et al., 2014; Lim et al., 2014; Chevalier et al., 2016; Andreasson and Pischel, 2018; Li et al., 2018; Yan et al., 2018a,b,c). Impressively, nanoaggregates of the released fluorophores ideally meet the hydrophobic requirements for long-term tracking, and the AIE character of the aggregates can well solve the notorious ACQ effect. Furthermore, we anticipate that AIE-active $\beta$-gal probes integrating light-up NIR characteristic in synergy with tunable aggregation behavior could make a breakthrough to detect endogenous $\beta$-gal with high-fidelity imaging in living subjects. During the response to $\beta$-gal, the aggregation behavior of the AIE probe altered from the molecular dissolved state into the aggregated state, achieving AIE-active NIR mode. In this case, the more AIEgens aggregate, the brighter their NIR emission becomes, making them suitable for in situ sensing and long-term tracking of biomolecules in living systems (Kwok et al., 2015; Peng et al., 2015; Yuan et al., 2016; Nicol et al., 2017). However, as far as we know, AIE-active $\beta$-gal probes possessing the characteristics of both localizable NIR fluorescence signal and long-term tracking mode are scarcely reported.

Herein, we developed an elaborated NIR AIE-active $\beta$-gal probe for enabling in situ and long-term tracking of endogenous enzyme activity (Scheme 1). Firstly, we focus on our groupdeveloped AIE building block of quinoline-malononitrile (QM) to overcome the enrichment quenching effect (Shi et al., 2013; Shao et al., 2014, 2015; Wang M. et al., 2018). Then, the lipophilic 2-(2-hydroxyphenyl) benzothiazole (HBT) moiety is covalently attached as an external $\pi$-conjugated backbone for extending the NIR emission. Furthermore, the masking of the phenolic hydroxyl group prohibits the excited-state intramolecular proton transfer (ESIPT) process and thus largely suppresses fluorescence
(Kwon and Park, 2011; Thorn-Seshold et al., 2012; Hu et al., 2014; Zhou et al., 2015; Cui et al., 2016; Chen L. et al., 2017; Chen Y. H. et al., 2017; Zhang P. et al., 2017; Sedgwick et al., 2018a,b; Zhou and Han, 2018). Finally, we utilized the hydrophilic galactose moiety as the $\beta$-gal-triggered unit for keeping probes in the fluorescence-off state with minimal background. When converted by $\beta$-gal, the probe releases free QM-HBT-OH, which is found to be nearly insoluble and aggregated in water and shows bright NIR fluorescence owing to the AIE building block with extended $\pi$-conjugated structure. By virtue of the NIR AIEactive performance of enzyme-catalyzed nanoaggregates, QMHBT- $\beta$ gal is capable of affording a localizable fluorescence signal and long-term tracking of endogenous $\beta$-gal activity. Our results demonstrate that the probe QM-HBT- $\beta$ gal has potential to be a powerful molecular tool to evaluate the biological activity of $\beta$-gal.

\section{EXPERIMENTAL SECTION}

\section{Materials and General Methods}

Unless especially stated, all solvents and chemicals were purchased from commercial suppliers in analytical grade and used without further purification. $\beta$-Galactosidase $(\beta$ gal) was supplied by $J \& K$ Scientific Ltd (Beijing, China). The ${ }^{1} \mathrm{H}$ and ${ }^{13} \mathrm{C}$ NMR spectra were recorded on a Bruker AM 400 spectrometer, using TMS as an internal standard. High-resolution mass spectrometry data were obtained with a Waters LCT Premier XE spectrometer. Absorption spectra were collected on a Varian Cary 500 spectrophotometer, and fluorescence spectra measurements were performed on a Varian Cary Eclipse fluorescence spectrophotometer. The time-dependent fluorescence measurements were conducted upon continuous illumination (Hamamatsu, LC8 Lightningcure, $300 \mathrm{~W}$ ). Dynamic light scattering (DLS) experiments were conducted with Zetasizer Nano-ZS (Malvern Instruments, Worcestershire, UK), and scanning electron microscope (SEM) images were operated on a JEOL JSM-6360 scanning electron microscope. Confocal fluorescence images were taken on a confocal laser scanning microscope (CLSM, Leica confocal microscope TCS SPS CFSMP).

\section{General Procedure for in vitro Monitoring $\beta$-gal Activity}

Probes were dissolved in dimethyl sulfoxide (DMSO, AR) to obtain 1-mM stock solutions. All UV-vis absorption and fluorescence spectra measurements were carried out in PBS/DMSO buffer solution $(7: 3, \mathrm{v} / \mathrm{v}, \mathrm{pH}=7.4,50 \mathrm{mM})$. In a 3-mL tube, PBS buffer $(2.1 \mathrm{~mL})$ and DMSO $(900 \mu \mathrm{L})$ solution were mixed, and then the probe $(30 \mu \mathrm{L})$ was added to obtain a final concentration of $10 \mu \mathrm{M}$. $\beta$-Gal was dissolved in a PBS buffer, and an appropriate volume was added to the sample solution. After rapid mixing of the solution, it was transferred to a $10 \times 10-\mathrm{mm}$ quartz cuvette and incubated at $37^{\circ} \mathrm{C}$ for in vitro detection. 


\section{Cell Experiment Cell Lines}

This study was performed in strict accordance with ethical standards including ethics committee approval and consent procedure, and adhered to standard biosecurity and institutional safety procedures. This study was performed in strict accordance with the NIH Guidelines for the Care and Use of Laboratory Animals (NIH Publication No. 85-23 Rev. 1985) and was approved by the Institutional Animal Care and Use Committee of National Tissue Engineering Center (Shanghai, China).

The human ovarian adenocarcinoma cell line SKOV-3 cells and the human epithelioid cervical carcinoma cell line HeLa cells were purchased from the Institute of Cell Biology (Shanghai, China). Cells were all propagated in T-75 flasks cultured at $37^{\circ} \mathrm{C}$ under a humidified $5 \% \mathrm{CO}_{2}$ atmosphere in RPMI-1640 medium or DMEM medium (GIBCO/Invitrogen, Camarillo, CA, USA), which were supplemented with $10 \%$ fetal bovine serum (FBS, Biological Industry, Kibbutz Beit Haemek, Israel) and 1\% penicillin-streptomycin $\left(10,000 \mathrm{U} \mathrm{mL}^{-1}\right.$ penicillin and $10 \mathrm{mg}$ $\mathrm{mL}^{-1}$ streptomycin, Solarbio Life Science, Beijing, China).

\section{In vitro Cytotoxicity Assay}

The cell cytotoxicity of QM-HBT- $\beta$ gal to SKOV-3 cells and HeLa cells was measured by 3-(4,5-dimethylthiazol-2-yl)-2,5diphenyltetrazolium bromide (MTT) assay. Cytotoxicity was evaluated by Cell Counting Kit-8 (Dojindo, Tokyo, Japan) according to the factory's instruction. Cells were plated in 96well plates in 0.1-mL volume of DMEM or RPMI-1640 medium with $10 \%$ FBS, at a density of $1 \times 10^{4}$ cells/well, and added with desired concentrations of SKOV-3. After incubation for $24 \mathrm{~h}$, absorbance was measured at $595 \mathrm{~nm}$ with a Tecan GENios Pro Multifunction Reader (Tecan Group Ltd., Maennedorf, Switzerland). Each concentration was measured in triplicate and used in three independent experiments. The relative cell viability was calculated by the following equation: cell viability (\%) = $\left(\mathrm{OD}_{\text {treated }} / \mathrm{OD}_{\text {control }}\right) \times 100 \%$.

\section{Cells Imaging}

Cells were seeded onto glass-bottom petri dishes in culture medium $(1.5 \mathrm{~mL})$ and allowed to adhere for $12 \mathrm{~h}$ before imaging. Probe QM-HBT- $\beta$ gal at a final concentration of $10 \mu \mathrm{M}$ (containing $0.1 \%$ DMSO) was added into culture medium and incubated for different times at $37^{\circ} \mathrm{C}$ under a humidified $5 \%$ $\mathrm{CO}_{2}$ atmosphere. Cells imaging was captured by using a confocal laser scanning microscope (Leica confocal microscope TCS SPS CFSMP) with a $60 \times$ oil immersion objective lens. The fluorescence signals of cells incubated with probes were collected at $650-700 \mathrm{~nm}$ under excitation wavelength at $460 \mathrm{~nm}$.

\section{Synthesis of Probe QM-HBT- $\beta$ gal Synthesis of Compound 1}

A mixture of 2-aminobenzenethiol (2 $\mathrm{g}, 16.0 \mathrm{mmol})$ and 2-hydroxy-3-methylbenzoic acid (2 g, $16.0 \mathrm{mmol})$ in polyphosphoric acid $(15 \mathrm{~mL})$ was heated in an oil bath at $180^{\circ} \mathrm{C}$ for $10 \mathrm{~h}$ under an argon atmosphere and then was cooled at room temperature. The mixture was then poured into ice, filtered, and the resulting solid product was washed with water, dried in air, and finally purified by column chromatography using dichloromethane/petroleum ether $(\mathrm{v} / \mathrm{v}, 2: 1)$ as the eluent to afford a white solid product $(1 \mathrm{~g})$ : yield $26 \% .{ }^{1} \mathrm{H}$ NMR (400 $\left.\mathrm{MHz}, \mathrm{CDCl}_{3}, \mathrm{ppm}\right): \delta=2.36\left(\mathrm{~s}, 3 \mathrm{H}, \mathrm{CH}_{3}-\mathrm{H}\right), 6.87(\mathrm{t}, J=8.0 \mathrm{~Hz}$, $1 \mathrm{H}$, phenyl-H), 7.27 (s, $1 \mathrm{H}$, phenyl-H), $7.41(\mathrm{t}, J=8.0 \mathrm{~Hz}, 1 \mathrm{H}$, phenyl-H), $7.50(\mathrm{t}, J=8.0 \mathrm{~Hz}, 1 \mathrm{H}$, phenyl- $\mathrm{H}), 7.56(\mathrm{~d}, J=8.0 \mathrm{~Hz}$, $1 \mathrm{H}$, phenyl-H), $7.90(\mathrm{~d}, J=8.0 \mathrm{~Hz}, 1 \mathrm{H}$, phenyl-H), $7.97(\mathrm{~d}, J=$ $8.0 \mathrm{~Hz}, 1 \mathrm{H}$, phenyl-H), 12.8 (s, $1 \mathrm{H},-\mathrm{OH}) .{ }^{13} \mathrm{C} \mathrm{NMR}(100 \mathrm{MHz}$, $\left.\mathrm{CDCl}_{3}, \mathrm{ppm}\right): \delta 169.81,156.29,151.83,133.69,132.71,126.63$, $126.07,125.43,122.07,121.49,119.00,116.02,16.08$. Mass spectrometry (ESI-MS, $m / z):[\mathrm{M}+\mathrm{H}]^{+}$calcd. for $\left[\mathrm{C}_{14} \mathrm{H}_{11} \mathrm{NOS}\right.$ $+\mathrm{H}]^{+}$242.0640; found 242.0636 .

\section{Synthesis of Compound 2}

Compound 1 (200 mg, $0.83 \mathrm{mmol}$ ) was dissolved in $10 \mathrm{~mL}$ of trifluoroacetic acid, and then, hexamethylenetetramine (174.5 mg, $1.25 \mathrm{mmol}$ ) was added. The mixture was heated in an oil bath at $90^{\circ} \mathrm{C}$ for $20 \mathrm{~h}$ under an argon atmosphere. The reaction mixture was then cooled to room temperature and poured into $6 \mathrm{M} \mathrm{HCl}(30 \mathrm{~mL})$ and extracted with $\mathrm{CH}_{2} \mathrm{Cl}_{2}$. The combined organic extracts were washed with saturated brine. Next, purification was done by column chromatography using dichloromethane as the eluent to afford the pure product as a whiteness solid (100 mg): yield 45\%. ${ }^{1} \mathrm{H} \mathrm{NMR}$ (400 $\mathrm{MHz}, \mathrm{CDCl}_{3}$, ppm): $\delta 2.42$ (s, 3H, $\left.\mathrm{CH}_{3}-\mathrm{H}\right), 7.47$ (t, $J=8.0 \mathrm{~Hz}, 1 \mathrm{H}$, phenyl-H), $7.55(\mathrm{t}, J=8.0 \mathrm{~Hz}, 1 \mathrm{H}$, phenyl-H), 7.80 (s, $1 \mathrm{H}$, phenyl-H), 7.95 $(\mathrm{d}, J=8.0 \mathrm{~Hz}, 1 \mathrm{H}$, phenyl-H), $8.01(\mathrm{~d}, J=8.0 \mathrm{~Hz}, 1 \mathrm{H}$, phenyl$\mathrm{H}), 8.11$ (d, $J=8.0 \mathrm{~Hz}, 1 \mathrm{H}$, phenyl-H), 9.92 (s, $1 \mathrm{H}, \mathrm{CHO}-\mathrm{H})$, 13.6 (s, $1 \mathrm{H},-\mathrm{OH}) .{ }^{13} \mathrm{C}$ NMR $\left(100 \mathrm{MHz}, \mathrm{CDCl}_{3}, \mathrm{ppm}\right): \delta 190.29$, $168.63,161.12,151.27,133.98,132.62,128.95,128.18,126.98$, $126.02,122.20,121.67,116.17,16.06$. Mass spectrometry (ESIMS, $m / z):[\mathrm{M}-\mathrm{H}]^{-}$calcd. for $\left[\mathrm{C}_{15} \mathrm{H}_{11} \mathrm{NO}_{2} \mathrm{~S}-\mathrm{H}\right]^{-}$268.0432; found 268.0436 .

\section{Synthesis of QM-HBT-OH}

Compound 2 (100 mg, $0.37 \mathrm{mmol}$ ) and 2-(1-ethyl-2methylquinolin- $4(1 \mathrm{H})$-ylidene)malononitrile (132 mg, 0.56 $\mathrm{mmol})$ were dissolved in acetonitrile $(20 \mathrm{ml})$ with piperidine $(0.5 \mathrm{ml})$. Then, the mixture was refluxed for $10 \mathrm{~h}$ under an argon atmosphere. The solvent was removed under reduced pressure, and then, the crude product was purified by silica gel chromatography using dichloromethane as the eluent to afford QM-HBT-OH as a red solid (50 mg): yield 28\%. ${ }^{1} \mathrm{H}$ NMR (400 $\left.\mathrm{MHz}, \mathrm{DMSO}-d_{6}, \mathrm{ppm}\right) \delta 1.45\left(\mathrm{t}, J=8.0 \mathrm{~Hz}, 3 \mathrm{H}, \mathrm{NCH}_{2} \mathrm{CH}_{3}-\mathrm{H}\right)$, $2.18\left(\mathrm{~s}, 3 \mathrm{H}, \mathrm{CH}_{3}-\mathrm{H}\right), 4.59$ (q, $\left.\mathrm{J}=8.0 \mathrm{~Hz}, 2 \mathrm{H}, \mathrm{NCH}_{2} \mathrm{CH}_{3}-\mathrm{H}\right)$, $7.09(\mathrm{~d}, J=16.0 \mathrm{~Hz}, 1 \mathrm{H}$, alkene-H), 7.15 (s, $1 \mathrm{H}$, phenyl-H), $7.29(\mathrm{t}, J=8.0 \mathrm{~Hz}, 1 \mathrm{H}$, phenyl-H), $7.42(\mathrm{~d}, J=8.0 \mathrm{~Hz}, 1 \mathrm{H}$, phenyl-H), $7.50(\mathrm{~d}, J=16.0 \mathrm{~Hz}, 1 \mathrm{H}$, alkene-H), $7.56(\mathrm{~d}, J=$ $8.0 \mathrm{~Hz}, 1 \mathrm{H}$, phenyl-H), 7.73(s, $1 \mathrm{H}$, phenyl-H), $7.87(\mathrm{t}, J=8.0 \mathrm{~Hz}$, $1 \mathrm{H}$, phenyl-H), $7.92(\mathrm{~d}, J=8.0 \mathrm{~Hz}, 1 \mathrm{H}$, phenyl-H), $8.00(\mathrm{~d}, J=$ $8.0 \mathrm{~Hz}, 1 \mathrm{H}$, phenyl-H), $8.04(\mathrm{t}, J=8.0 \mathrm{~Hz}, 1 \mathrm{H}$, phenyl-H), 8.24 (d, $J=8.0 \mathrm{~Hz}, 1 \mathrm{H}$, phenyl-H), 8.90 (d, $J=8.0 \mathrm{~Hz}, 1 \mathrm{H}$, phenyl-H). ${ }^{13} \mathrm{C}$ NMR $\left(100 \mathrm{MHz}, \mathrm{DMSO}-d_{6}, \mathrm{ppm}\right): \delta 165.84,151.86,150.47$, $150.34,143.33,138.18,135.37,132.98,130.47,128.51,124.97$, $124.23,122.31,121.25,120.70,120.40,117.76,104.59,43.02$, $17.53,13.63$. Mass spectrometry (ESI-MS, $m / z)$ : $[\mathrm{M}-\mathrm{H}]^{-}$calcd. for $\left[\mathrm{C}_{30} \mathrm{H}_{22} \mathrm{~N}_{4} \mathrm{OS}-\mathrm{H}\right]^{-}$485.1436; found 485.1439 . 


\section{Synthesis of QM-HBT- $\beta$ galAc}

QM-HBT-OH (100 mg, $0.21 \mathrm{mmol}$ ) and tetra-O-acetyl- $\alpha$-Dgalactopyranosyl-1-bromide ( $150 \mathrm{mg}, 0.36 \mathrm{mmol})$ were dissolved in acetonitrile $(15 \mathrm{ml})$ with $\mathrm{Cs}_{2} \mathrm{CO}_{3}(359 \mathrm{mg}, 1.10 \mathrm{mmol})$ and $\mathrm{Na}_{2} \mathrm{SO}_{4}(125 \mathrm{mg}, 0.88 \mathrm{mmol})$ under argon protection at room temperature. The mixture then was stirred at room temperature for $4 \mathrm{~h}$. After filtration, the solvent was removed under reduced pressure. The residue was taken up in sat. $\mathrm{NH}_{4} \mathrm{Cl}$ and extracted with $\mathrm{CH}_{2} \mathrm{Cl}_{2}$. Next, the solution was dried over anhydrous $\mathrm{Na}_{2} \mathrm{SO}_{4}$, and the solvent was removed by evaporation again. Finally, the crude product was purified by silica gel chromatography using dichloromethane/methanol (100:1) to afford the desired product QM-HBT- $\beta$ galAc as a red solid (30 mg): yield $18 \% .{ }^{1} \mathrm{H}$ NMR (400 MHz, DMSO- $\left.d_{6}, \mathrm{ppm}\right) \delta$ $1.41\left(\mathrm{t}, J=8.0 \mathrm{~Hz}, 3 \mathrm{H}, \mathrm{NCH}_{2} \mathrm{CH}_{3}-\mathrm{H}\right), 1.76$ (s, 3H, acetyl$\mathrm{H}), 1.94(\mathrm{~s}, 3 \mathrm{H}$, acetyl-H), $1.99(\mathrm{~s}, 3 \mathrm{H}$, acetyl-H), $2.08(\mathrm{~s}, 3 \mathrm{H}$, acetyl-H), $2.46\left(\mathrm{~s}, 3 \mathrm{H}, \mathrm{CH}_{3}-\mathrm{H}\right), 3.56\left(\mathrm{~m}, 2 \mathrm{H}, \mathrm{CH}_{2} \mathrm{OCOCH}_{3}\right)$, $4.06(\mathrm{t}, J=8.0 \mathrm{~Hz}, 1 \mathrm{H}$, galactose- $\mathrm{H}), 4.62(\mathrm{q}, J=8.0 \mathrm{~Hz}, 2 \mathrm{H}$, $\left.\mathrm{NCH}_{2} \mathrm{CH}_{3}-\mathrm{H}\right), 5.16(\mathrm{~s}, 1 \mathrm{H}$, galactose- $\mathrm{H}), 5.24(\mathrm{~s}, 1 \mathrm{H}$, galactose$\mathrm{H}), 5.34(\mathrm{~s}, 1 \mathrm{H}$, galactose- $\mathrm{H}), 5.48(\mathrm{~m}, 1 \mathrm{H}$, galactose- $\mathrm{H}), 7.06$ (s, 1H, phenyl-H), $7.47(\mathrm{t}, J=8.0 \mathrm{~Hz}, 1 \mathrm{H}$, phenyl-H), $7.54(\mathrm{t}$, $J=8.0 \mathrm{~Hz}, 1 \mathrm{H}$, phenyl-H), $7.60(\mathrm{~d}, J=16.0 \mathrm{~Hz}, 2 \mathrm{H}$, alkene$\mathrm{H}), 7.65(\mathrm{~d}, J=8.0 \mathrm{~Hz}, 1 \mathrm{H}$, phenyl-H), $7.95(\mathrm{t}, J=8.0 \mathrm{~Hz}, 1 \mathrm{H}$, phenyl-H), 8.01(s, $1 \mathrm{H}$, phenyl-H), $8.11(\mathrm{~m}, 2 \mathrm{H}$, phenyl- $\mathrm{H}), 8.19$ (d, $J=8.0 \mathrm{~Hz}, 1 \mathrm{H}$, phenyl-H), $8.37(\mathrm{~s}, 1 \mathrm{H}$, phenyl-H), $8.95(\mathrm{~d}$, $J=8.0 \mathrm{~Hz}, 1 \mathrm{H}$, phenyl-H). ${ }^{13} \mathrm{C}$ NMR $\left(100 \mathrm{MHz}, \mathrm{DMSO}-d_{6}\right.$, ppm): $\delta 169.67,169.45,163.39,167.27,152.34,151.67,149.11$, $138.43,137.75,135.94,133.74,132.40,132.29,129.09,127.67$, $126.03,125.12,122.78,121.61,120.61,118.12,107.28,99.94$, $91.56,70.10,69.77,69.18,68.22,67.00,64.11,61.19,60.60,47.20$, 43.84, 20.52, 20.11, 16.21, 13.69. Mass spectrometry (ESI-MS, $m / z):[\mathrm{M}+\mathrm{H}]^{+}$calcd. for $\left[\mathrm{C}_{44} \mathrm{H}_{40} \mathrm{~N}_{4} \mathrm{O}_{10} \mathrm{~S}+\mathrm{H}\right]^{+}$817.2543; found 817.2548 .

\section{Synthesis of QM-HBT- $\beta$ gal}

QM-HBT- $\beta$ galAc $(50 \mathrm{mg}, 0.06 \mathrm{mmol}$ ) was added to $\mathrm{MeONa}$ (70 $\mathrm{mg}, 1.3 \mathrm{mmol})$ in methanol $(10 \mathrm{ml})$, and the mixture was stirred at room temperature for $4 \mathrm{~h}$. Then, the reaction mixture was neutralized with Amberlite IR-120 plus $\left(\mathrm{H}^{+}\right)$. After Amberlite IR-120 plus $\left(\mathrm{H}^{+}\right)$was filtered off, the solvent was removed by evaporation. Finally, the crude product was purified by silica gel chromatography using dichloromethane/methanol (40:1) to afford the desired product QM-HBT- $\beta$ gal $(16 \mathrm{mg}):{ }^{1} \mathrm{H}$ NMR (400 MHz, DMSO- $\left.d_{6}, \mathrm{ppm}\right) \delta 1.41(\mathrm{t}, J=8.0 \mathrm{~Hz}, 3 \mathrm{H}$, $\mathrm{NCH}_{2} \mathrm{CH}_{3}-\mathrm{H}$ ), 2.53 (s, 3H, $\left.\mathrm{CH}_{3}-\mathrm{H}\right), 3.07-3.26$ (m, 4H, -OH), $3.27\left(\mathrm{~m}, 2 \mathrm{H},-\mathrm{CH}_{2} \mathrm{OH}\right), 3.28(\mathrm{~m}, 2 \mathrm{H}$, galactose $-\mathrm{H}), 3.61(\mathrm{~d}, J=$ $8.0 \mathrm{~Hz}, 1 \mathrm{H}$, galactose- $\mathrm{H}), 3.87(\mathrm{~d}, J=8.0 \mathrm{~Hz}, 1 \mathrm{H}$, galactose- $\mathrm{H})$, $4.62\left(\mathrm{q}, J=8.0 \mathrm{~Hz}, 2 \mathrm{H}, \mathrm{NCH}_{2} \mathrm{CH}_{3}-\mathrm{H}\right), 4.77(\mathrm{~d}, J=8.0 \mathrm{~Hz}$, $1 \mathrm{H}$, galactose- $\mathrm{H}), 7.07(\mathrm{~s}, 1 \mathrm{H}$, phenyl- $\mathrm{H}), 7.44(\mathrm{t}, J=8.0 \mathrm{~Hz}$, $1 \mathrm{H}$, phenyl-H), $7.52(\mathrm{~d}, J=8.0 \mathrm{~Hz}, 1 \mathrm{H}$, phenyl- $\mathrm{H}), 7.58(\mathrm{~d}$, $J=16.0 \mathrm{~Hz}, 2 \mathrm{H}$, phenyl-H), $7.64(\mathrm{~d}, J=8.0 \mathrm{~Hz}, 1 \mathrm{H}$, phenyl$\mathrm{H}), 7.95(\mathrm{~d}, J=8.0 \mathrm{~Hz}, 1 \mathrm{H}$, phenyl-H), 7.97 (s, $1 \mathrm{H}$, phenyl$\mathrm{H}), 8.09$ (d, $J=16.0 \mathrm{~Hz}, 1 \mathrm{H}$, alkene-H), $8.11(\mathrm{~d}, J=8.0 \mathrm{~Hz}$, $1 \mathrm{H}$, phenyl-H), 8.12 (d, $J=16.0 \mathrm{~Hz}, 1 \mathrm{H}$, alkene-H), 8.39 (d, $J$ $=8.0 \mathrm{~Hz}, 1 \mathrm{H}$, phenyl-H), $8.95(\mathrm{~d}, J=8.0 \mathrm{~Hz}, 1 \mathrm{H}$, phenyl- $\mathrm{H})$. ${ }^{13} \mathrm{C}$ NMR (100 MHz, DMSO- $\left.d_{6}, \mathrm{ppm}\right): \delta 163.97,153.87,152.25$, $151.58,149.12,138.67,137.72,136.00,133.68,132.49,132.05$,
$131.29,128.18,127.56,125.08,125.01,124.95,122.52,121.71$, $120.89,120.58,119.15,118.07,107.19,104.47,75.48,73.11,71.11$, $67.66,59.79,47.10,43.85,16.81,13.71$. Mass spectrometry (ESIMS, $m / z):[\mathrm{M}+\mathrm{H}]^{+}$calcd. for $\left[\mathrm{C}_{36} \mathrm{H}_{32} \mathrm{~N}_{4} \mathrm{O}_{6} \mathrm{~S}+\mathrm{H}\right]^{+} 649.2121$; found 649.2123 .

\section{RESULTS AND DISCUSSION}

\section{Design and Synthesis}

In our strategy, QM is employed as the AIE building block along with generating modifiable sites for functionalization, which could perform controllable NIR emission via tuning electron-donor ability (Shi et al., 2013; Shao et al., 2014, 2015; Wang M. et al., 2018). Particularly, neighboring HBT moiety is covalent attached as hydrophobic $\pi$-conjugated backbone, efficiently extending emission wavelength to the NIR region. Finally, a $\beta$-gal activatable unit is grafted at the position of phenolic hydroxyl group, blocking the ESIPT process and endowing the elaborated probe QM-HBT-ßgal with moderate water solubility. In consequence, the molecular dissolved state in the aqueous system renders the probe almost non-fluorescent. After being specifically hydrolyzed by $\beta$-gal, hydrophobic QM-HBT-OH can be released and aggregated with a remarkable light-up AIE-active fluorescent signal, which could be well retained in the reaction site and emit strong fluorescence for long-term tracking endogenous $\beta$-gal activity. The synthetic route for the probe is depicted in the Materials and General Methods (Scheme S1), which was fully characterized by ${ }^{1} \mathrm{H}$ and ${ }^{13} \mathrm{C}$ NMR and high-resolution mass spectrometry (HRMS) (Figures S10-S24).

\section{Aggregation-Induced Emission Properties of QM-HBT- $\beta$ gal and QM-HBT-OH}

Initially, the AIE properties of QM-HBT- $\beta$ gal and QM-HBT$\mathrm{OH}$ were investigated in the water/THF mixed solvents with different water volume fractions $\left(f_{\mathrm{w}}=0-90 \%\right)$ in Figure 1. Actually, both compounds showed two absorption peaks at 360 and $440 \mathrm{~nm}$, respectively. The absorption spectrum of QMHBT- $\beta$ gal displayed only slight changes with the increasing $f_{\mathrm{w}}$ (Figure 1A), but that of QM-HBT-OH significantly descended when the $f_{\mathrm{w}}$ exceeded $70 \%$ (Figure 1D), resulting from the light scattering effect of the well-formed nanoaggregates. As expected, the hydrophilic galactose group makes QM-HBT- $\beta$ gal in the molecular dissolved state in water, which exhibits nonemission in various water/THF mixtures (Figures 1B,C), with a quantum yield $(\Phi)$ of 0.1 using Rhodamine B as a reference compound. In contrast, QM-HBT-OH showed distinct lightup AIE characteristics. By increasing the $f_{\mathrm{w}}$ from 0 to $60 \%$, the emission intensity increased slowly, accompanied by an obvious bathochromic shift (Figure 1E). Further addition of water leads to a sharp and dramatic enhancement in fluorescence intensity ( $\Phi=3.6 \%$ ), which correlates well with the formation of nanoaggregates in poorer solvents (Figure 1F). Here, the initial fluorescence-off state of QM-HBT-ßgal and significant AIE-active NIR fluorescence of QM-HBT-OH in aggregated state made it as an ideal candidate for tracking $\beta$-gal. 


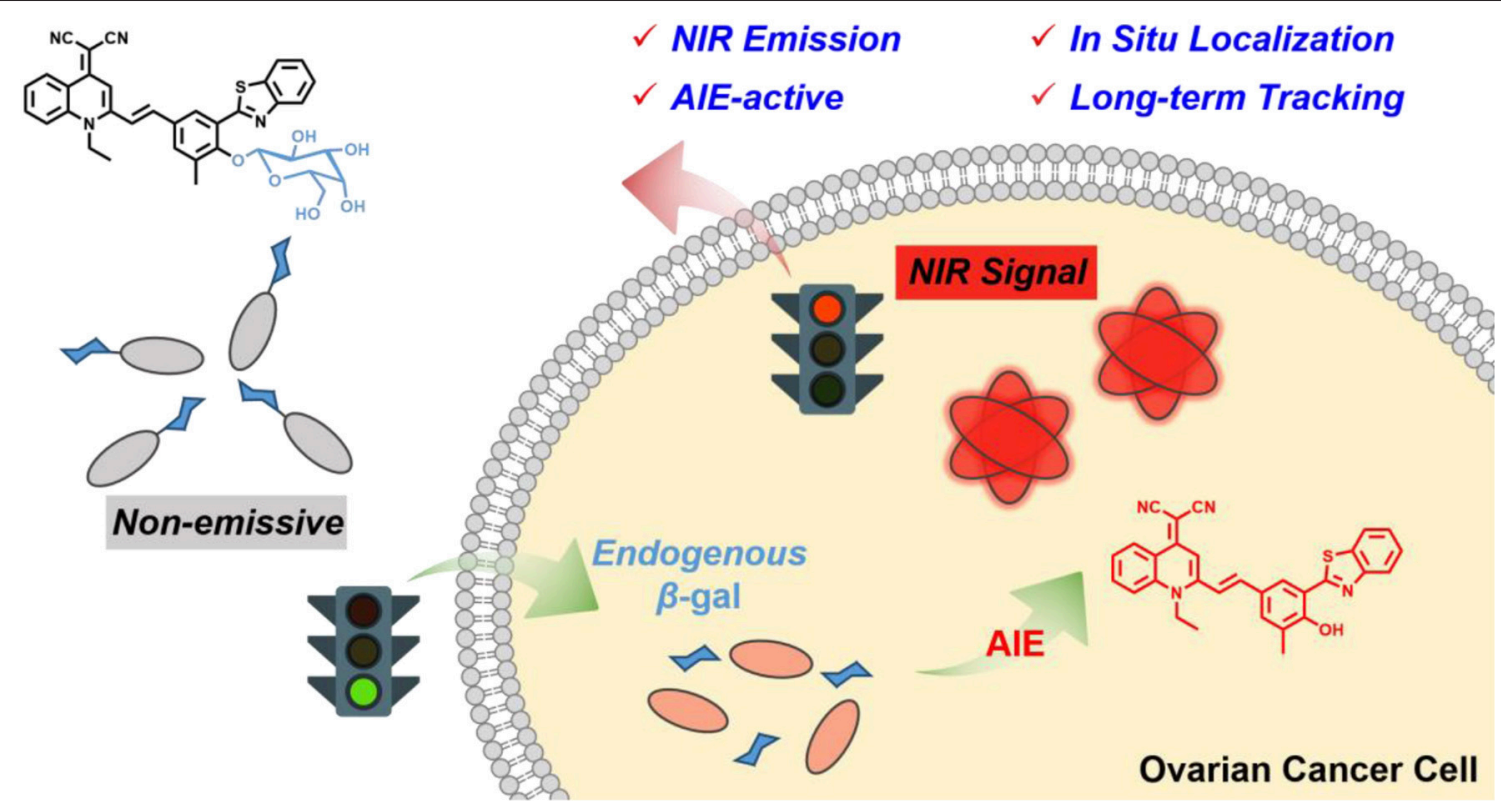

SCHEME 1 | Schematic illustration of an enzyme $\beta$-gal-regulated liberation strategy for on-site sensing and long-term tracking.
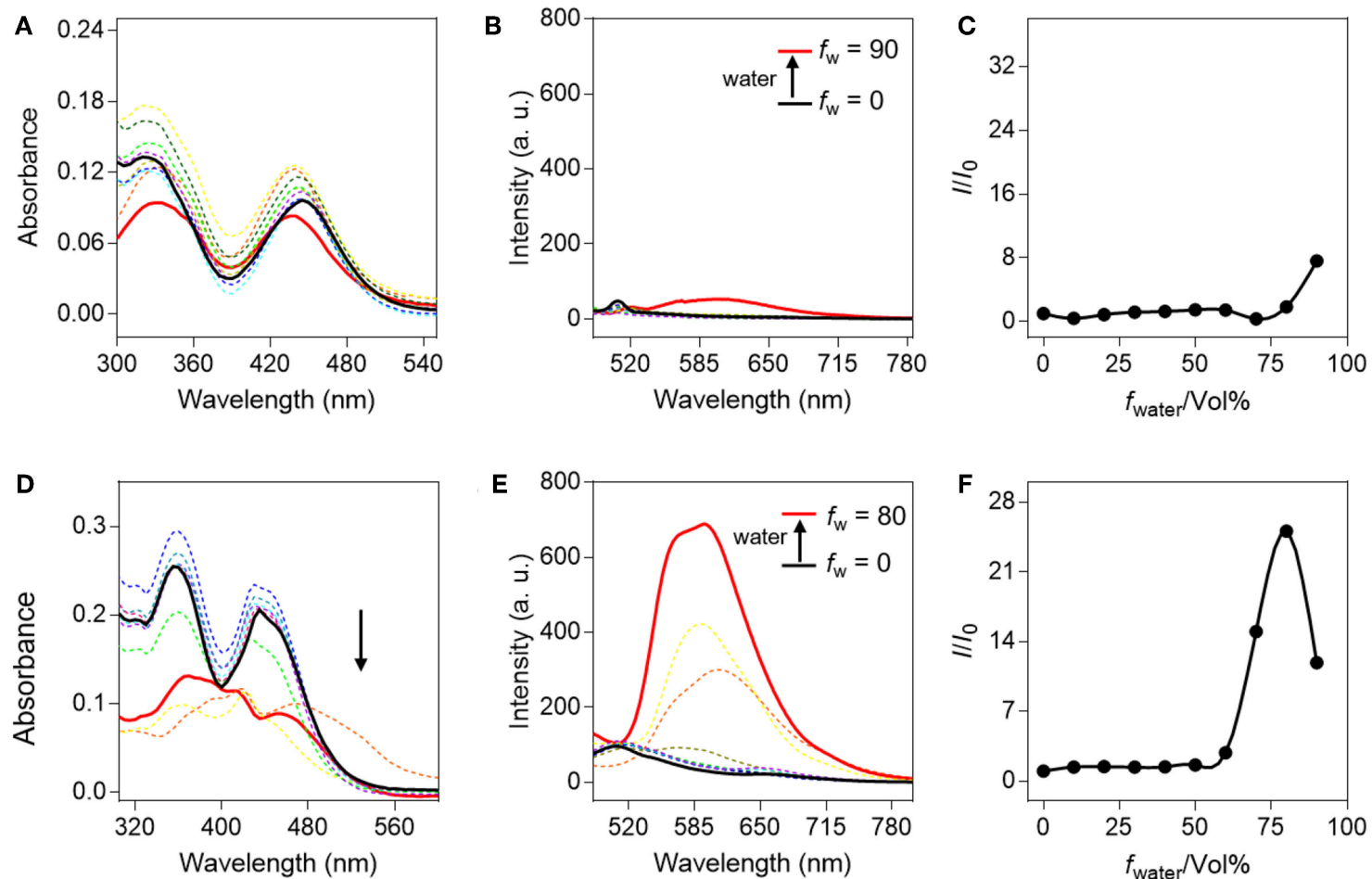

FIGURE 1 | Spectral properties of QM-HBT- $\beta$ gal and QM-HBT-OH with different water fractions $\left(f_{\mathrm{W}}\right)$ in a mixture of water/tetrahydrofuran. (A) Absorption spectra, (B) emission spectra, and (C) I/IO plots of QM-HBT- $\beta$ gal (10 $\mu \mathrm{M})$; (D) absorption spectra, (E) emission spectra, and (F) //Io plots of QM-HBT-OH (10 $\mu$ M), where / is the fluorescence intensity at $620 \mathrm{~nm}$ and $I_{0}$ is the fluorescence intensity of QM-HBT- $\beta$ gal or QM-HBT-OH in $0 \%$ water, $\lambda$ ex $=460 \mathrm{~nm}$. 


\section{Spectroscopic Properties and Optical Response to $\beta$-gal}

A smart AIE-active $\beta$-gal NIR fluorescent probe should significantly alter its fluorescence characteristic upon response to $\beta$-gal. With the probe QM-HBT- $\beta$ gal in hand, we investigated the optical response of the probe to $\beta$-gal in the aqueous solution (PBS/DMSO $=7: 3, \mathrm{v} / \mathrm{v}, 50 \mathrm{mM}, \mathrm{pH}=7.4$ ) at $37^{\circ} \mathrm{C}$. QM-HBT-ßgal has a broad absorption band at $440 \mathrm{~nm}$, and the absorbance peak decreased gradually with the addition of $\beta$-gal (Figure S1). As shown in Figures 2A,B, a distinct NIR fluorescence enhancement at $650 \mathrm{~nm}$ was observed from QMHBT- $\beta$ gal upon the addition of $10 \mathrm{U} \beta$-gal, accompanied by a significant bathochromic shift in emission spectra. It could be interpreted that the QM-HBT- $\beta$ gal can be specifically hydrolyzed by $\beta$-gal and then spontaneously form nanoaggregates QM$\mathrm{HBT}-\mathrm{OH}$ with a remarkable AIE-active fluorescent signal, which is confirmed by Figures S2, S3, and we observe in situ generation of about 200-nm nanoaggregates by DLS and SEM characterization. In addition, the enhancement of fluorescence intensity is dependent on the incubation time with $\beta$-gal, leveling off at around $6 \mathrm{~h}$. In contrast, negligible fluorescence intensity change of QM-HBT- $\beta$ gal was observed without the addition of $\beta$-gal, indicative of the moderate and efficient enzyme response rate toward $\beta$-gal. Further, we performed the titration to study the enzymatic fluorescence response of QM-HBT- $\beta$ gal (Figure 2C). With the increase of $\beta$-gal concentration (0-12 U),
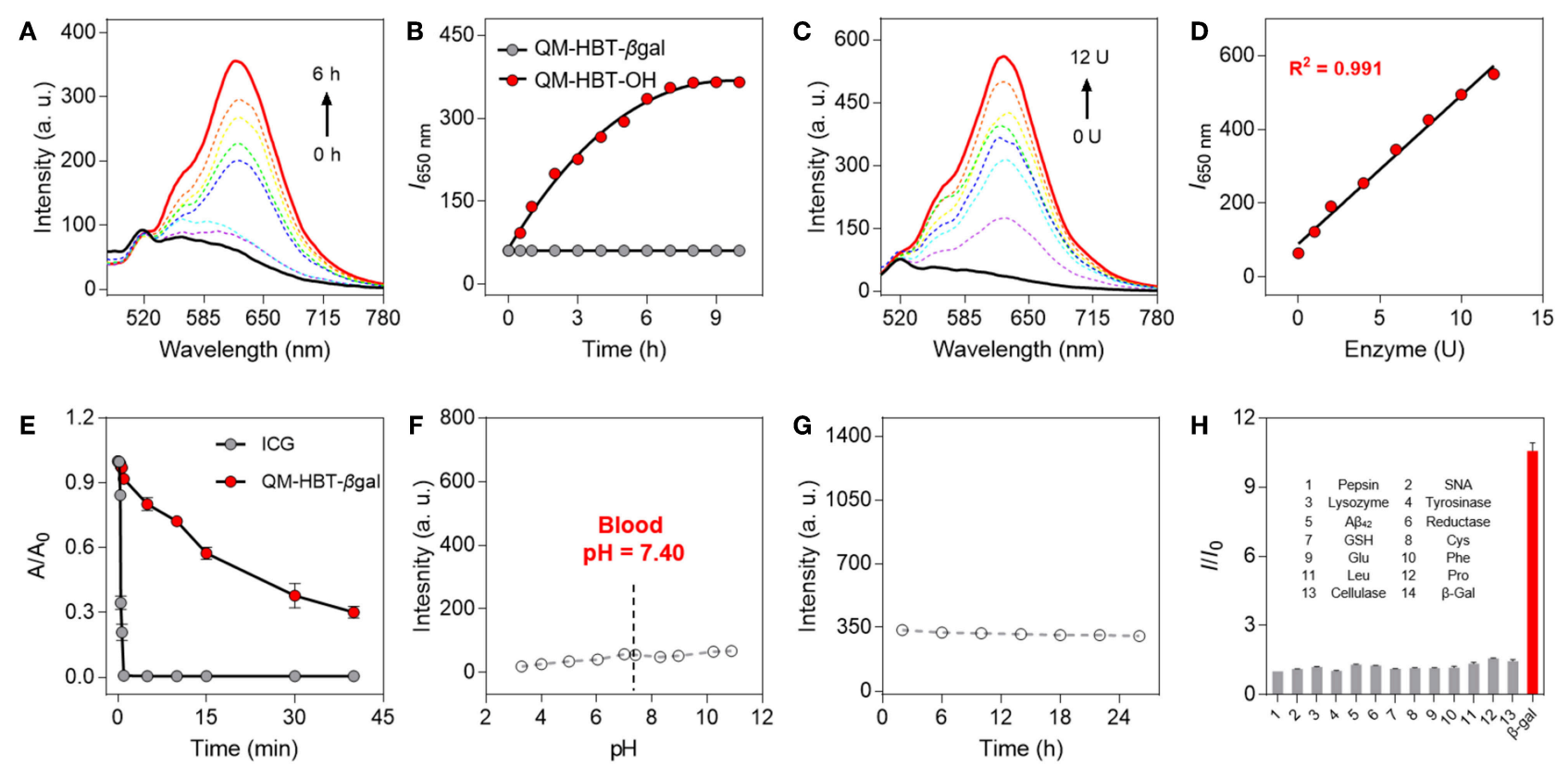

I

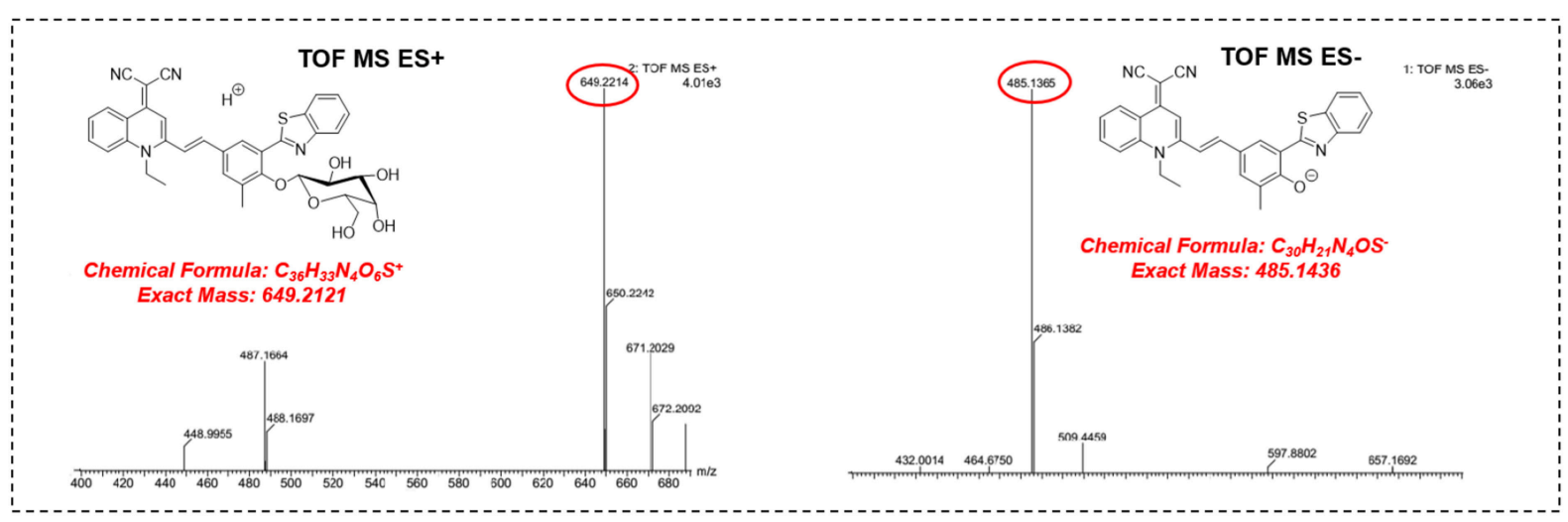

FIGURE 2 | (A) Time-dependent fluorescence spectra of QM-HBT- $\beta$ gal $(10 \mu \mathrm{M})$ with $10 \cup \beta$-gal in aqueous solution (PBS/DMSO = 7:3, v/v, 50 $\mathrm{mM}$, pH = 7.4) at $37^{\circ} \mathrm{C}$. (B) Time dependence of $\mathrm{I}_{650} \mathrm{~nm}$ for QM-HBT- $\beta$ gal before (black) and after (red) adding $\beta$-gal, $\lambda_{\text {ex }}=460 \mathrm{~nm}$. (C) Fluorescence spectra of QM-HBT- $\beta$ gal (10 $\mu$ M) upon treatment with increasing concentrations of $\beta$-gal $(0-12 \mathrm{U})$ after incubation for $6 \mathrm{~h}$. (D) Fluorescence intensity $\mathrm{I}_{650} \mathrm{~nm}$ as a function of $\beta$-gal concentration after incubation for $6 \mathrm{~h}$. (E) Time-dependent fluorescence intensity of ICG (10 $\mu \mathrm{M}$, monitored at $812 \mathrm{~nm}$, and $\left.\lambda_{\mathrm{ex}}=780 \mathrm{~nm}\right)$ and QM-HBT- $\beta$ gal (10 $\mu \mathrm{M}$, monitored at $650 \mathrm{~nm}$, and $\lambda_{\mathrm{ex}}=460 \mathrm{~nm}$ ) under sustained illumination. (F) Fluorescence intensity at $650 \mathrm{~nm}$ of QM-HBT- $\beta$ gal remaining stable in various pH values and (G) fresh mouse serum over $24 \mathrm{~h}$ at $37^{\circ} \mathrm{C}$. (H) Fluorescence responses of QM-HBT- $\beta$ gal $(10 \mu \mathrm{M})$ upon incubation with $\beta$-gal (10 U) and various other analytes (100 equiv.) in aqueous solution (PBS/DMSO $=7: 3, \mathrm{v} / \mathrm{v}, 50 \mathrm{mM}, \mathrm{pH}=7.4$ ) at $37^{\circ} \mathrm{C}, \lambda_{\mathrm{ex}}=460 \mathrm{~nm}$. (I) High-resolution mass spectrometry (HRMS) demonstrating the enzyme-activatable mechanism and showing the cleavage product $\mathrm{QM}-\mathrm{HBT}-\mathrm{OH}$. 


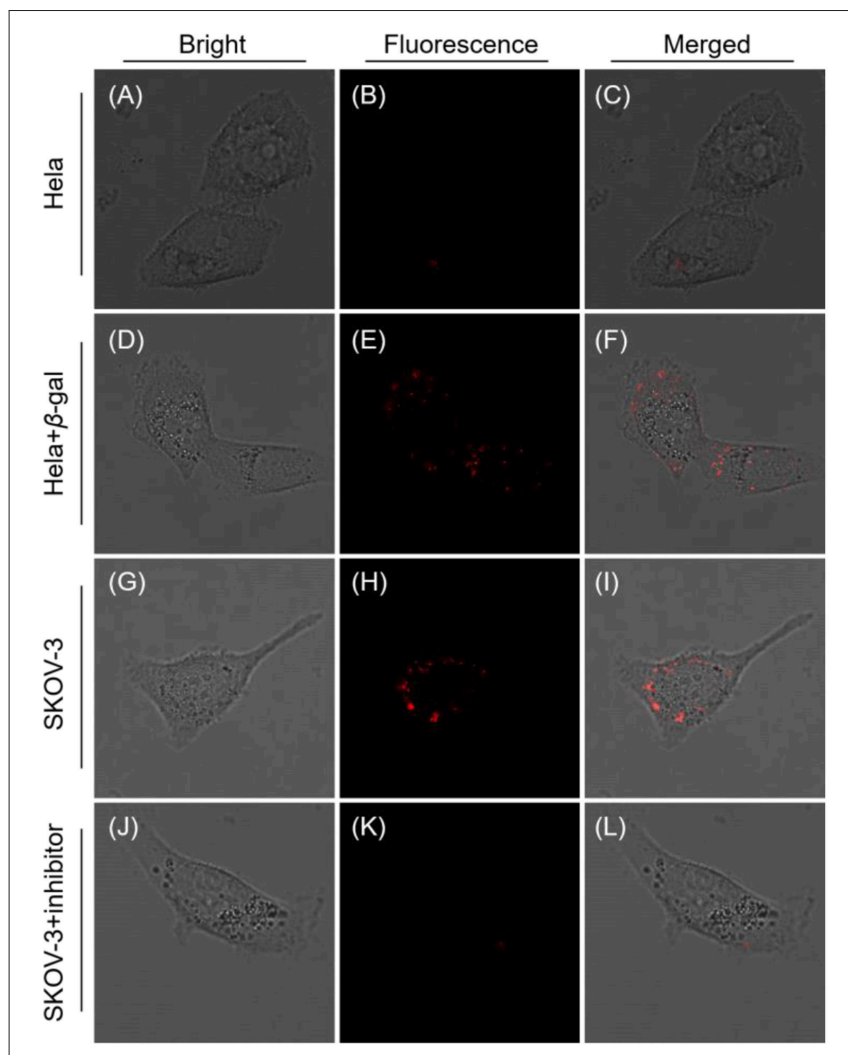

FIGURE 3 | Confocal laser scanning microscopy (CLSM) images of Hela and SKOV-3 cells incubated with QM-HBT- $\beta$ gal $(10 \mu \mathrm{M})$ for $4 \mathrm{~h}$ : (A-C) Hela cells, (D-F) Hela cells pretreated with $1 \mathrm{mM} \beta$-gal for $0.5 \mathrm{~h}$. (G-I) SKOV-3 cells, and (J-L) SKOV-3 cells pretreated with $1 \mathrm{mM}$ inhibitor for $0.5 \mathrm{~h}$. The window of fluorescence emission collection is $650-700 \mathrm{~nm}, \lambda_{\mathrm{ex}}=460 \mathrm{~nm}$.

the fluorescence intensity around $650 \mathrm{~nm}$ of QM-HBT- $\beta$ gal gradually enhanced and showed a linear correlation vs. the concentration of $\beta$-gal in the range of $0-12 \mathrm{U}$ with a correlation coefficient of 0.991 (Figure 2D). Obviously, these remarkable characteristics of QM-HBT- $\beta$ gal indicated that it could be capable of detecting $\beta$-gal activity.

\section{Photostability and Selectivity}

The high photostability of QM-HBT- $\beta$ gal is very crucial to perform long-term tracking and high-fidelity imaging of enzyme activity in preclinical applications. Compared with the commercial FDA-approved NIR contrast agent ICG, the time-dependent absorbance measurements were also conducted to evaluate the photostability of QM-HBT- $\beta$ gal upon continuous illumination (Hamamatsu, LC8 Lightningcure, $300 \mathrm{~W}$ ) in aqueous solution (Figure 2E). As calculated, the half-life of QM-HBT-Bgal $(\sim 1,500 s)$ is 60 -fold longer than that of ICG ( $\sim 25 \mathrm{~s}$ ), suggestive of excellent photostability of QM-HBT$\beta$ gal, which further confirmed its potential application in long-term tracking.

We further study the stability of the probe QM-HBT- $\beta$ gal in different $\mathrm{pH}$ values. Figure 2F indicates excellent stability of QMHBT- $\beta$ gal in various $\mathrm{pH}$ values (3-11), and its excellent stability remained in fresh mouse serum over $24 \mathrm{~h}$ (Figure 2G). In addition, the probe QM-HBT- $\beta$ gal exhibits excellent $\mathrm{pH}$ stability in the medium of FBS (Figures S4, S8 and S9). Furthermore, prior to investigating endogenous $\beta$-gal activity in living cells, the specificity of QM-HBT- $\beta$ gal toward $\beta$-gal was also evaluated with potential competitive species including amino acids, enzymes, serum markers, and metabolic substances. As shown in Figure $2 \mathbf{H}$, compared with $\beta$-gal, nearly negligible fluorescence change of QM-HBT- $\beta$ gal makes it a promising candidate to achieve accurate detection under practical applications.

\section{Sensing Mechanism}

For gaining insight into the activation mechanism of probe QM-HBT- $\beta$ gal for enzyme $\beta$-gal, and then in situ release of QM-HBT-OH as NIR AIEgens, we acquired high-resolution mass spectrometry to confirm this proposed mechanism. In the electrospray ionization (ESI)-MS spectra of QM-HBT$\beta$ gal with $\beta$-gal, the peaks of QM-HBT- $\beta$ gal and QM-HBT$\mathrm{O}^{-}$were found at $\mathrm{m} / \mathrm{z} 649.2214$ and 485.1365 (Figure 2I), respectively. The result clearly indicated that QM-HBT- $\beta$ gal could be specifically activated by enzyme $\beta$-gal, and release QMHBT-OH as NIR AIEgens.

\section{Imaging of Endogenous $\beta$-gal in Living Cells}

In order to study the biocompatibility of probe QM-HBT$\beta$ gal, standard 5-diphenyltetrazolium bromide (MTT) assays in human ovarian carcinoma cells (SKOV-3 cells) and human epithelioid cervical carcinoma cells (Hela cells) were carried out, respectively. As is observed in Figure S5, experimental results verified that probe QM-HBT- $\beta$ gal has almost no cytotoxicity toward living cells.

Taken all together, the probe QM-HBT- $\beta$ gal is anticipated to be capable of accurately detecting the endogenous enzyme activity in living cells with in situ formation of AIEgen nanoaggregates. To demonstrate this potential, SKOV-3 cells were used as a model, because they overexpress $\beta$-gal (Asanuma et al., 2015), while Hela cells without expressed $\beta$-gal were used as a negative control model. As depicted in Figures 3A-C, no fluorescence was observed at the Hela cells, in accordance with the weak fluorescence spectrum of QM-HBT- $\beta$ gal. In contrast, by adding an exogenous $10 \mathrm{U} \beta$-gal to Hela cells, a significant enhancement of fluorescence (Figures 3D-F) was observed due to further the enzyme conversion process. As demonstrated, the enzyme-catalyzed AIE-active NIR fluorescent probe QM-HBT- $\beta$ gal can be used to detect $\beta$-gal in cancer cells. Impressively, SKOV-3 cells, which were treated with QM-HBT$\beta$ gal for $3 \mathrm{~h}$, exhibit strong fluorescence in its NIR fluorescent channel (Figures 3G-I), suggesting its possible reaction with endogenous $\beta$-gal in the cells. These AIE-active signals were interpreted as being insoluble aggregates of released QM-HBT$\mathrm{OH}$, only occurring at the site where the probe is reacted with $\beta$-gal. To verify that the fluorescence change was caused by endogenous $\beta$-gal, $1 \mathrm{mM} D$-galactose (an inhibitor of $\beta$-gal; Portaccio et al., 1998) was used to pretreat the cells for $0.5 \mathrm{~h}$. Negligible fluorescence signal was observed in the NIR channel (Figures 3J-L), indicating that the enhancement in SKOV-3 cells indeed results from the endogenous $\beta$-gal activity. 
To establish the precise intracellular localization, co-staining experiments of QM-HBT- $\beta$ gal were performed with SKOV3 cells. The AIE-active probe QM-HBT- $\beta$ gal co-staining with commercially available Golgi-Tracker Green, LysoTracker Red, ER-Tracker Red, and Mito-Tracker Red shows an obvious colocalization characteristic (Figure 4). Specifically, the red channel

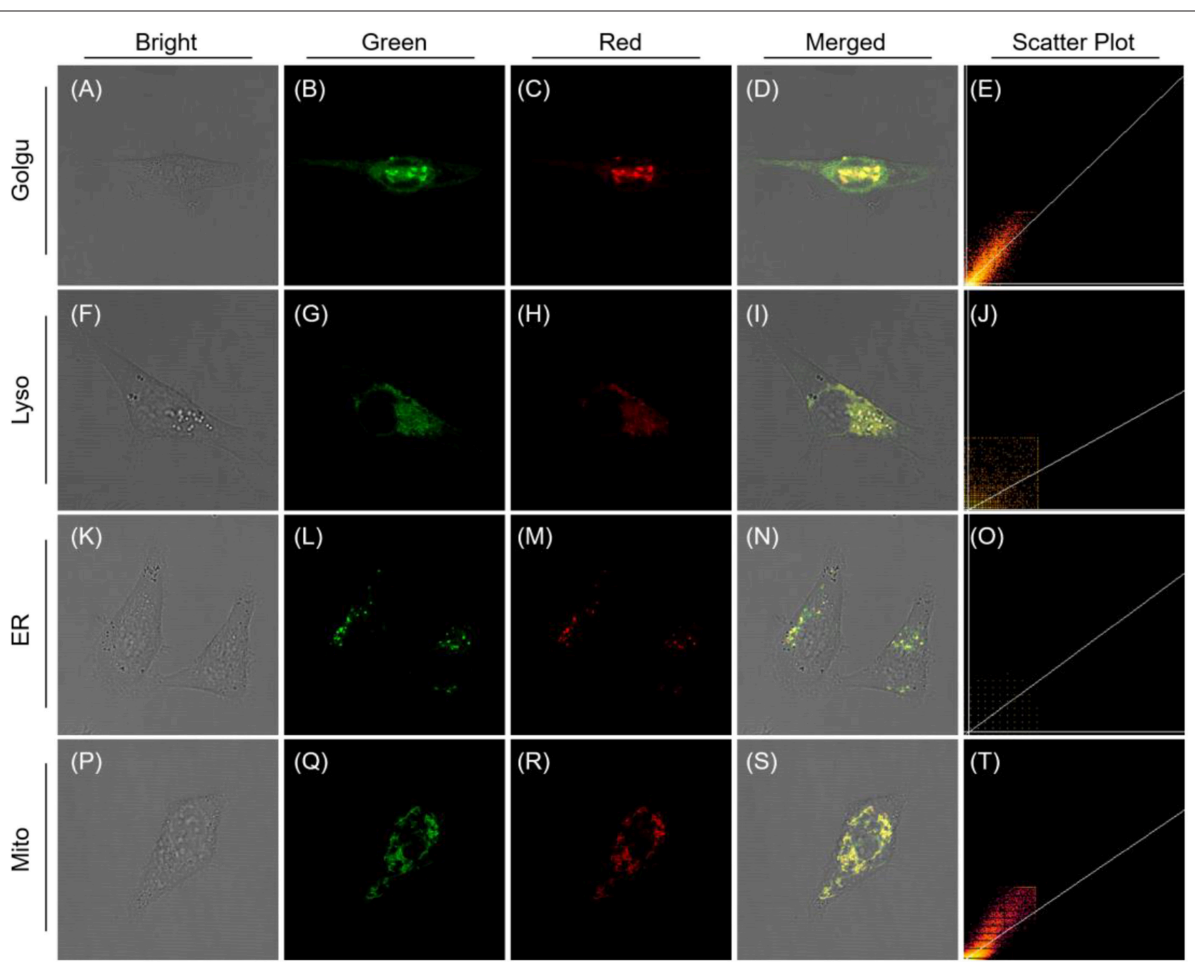

FIGURE 4 | CLSM images for intracellular localization of QM-HBT- $\beta$ gal in SKOV-3 cells. Cells were incubated with QM-HBT- $\beta$ gal (10 $\mu$ M) for $2 \mathrm{~h}$ and then co-stained with $1 \mu \mathrm{M}$ Golgi-Tracker Green (BODIPY FL C5-Ceramide) (A-E), 100 nM Lyso-Tracker Red DND-99 (F-J), 1 MM ER-Tracker Red (BODIPY TR Glibenclamide) (K-O), and 200 nM Mito-Tracker Red for 30 min (P-T), respectively. The green channel at 510-530 nm for Golgi-Tracker Green (B), $\lambda$ ex = 505 nm; $610-630$ nm for ER-Tracker Red (L), 590-610 nm for Lyso-Tracker Red DND-99 (G) and Mito-Tracker Red (Q), $\lambda_{\text {ex }}=561 \mathrm{~nm}$. The red channel at $650-700 \mathrm{~nm}, \lambda_{\text {ex }}=460 \mathrm{~nm}$.

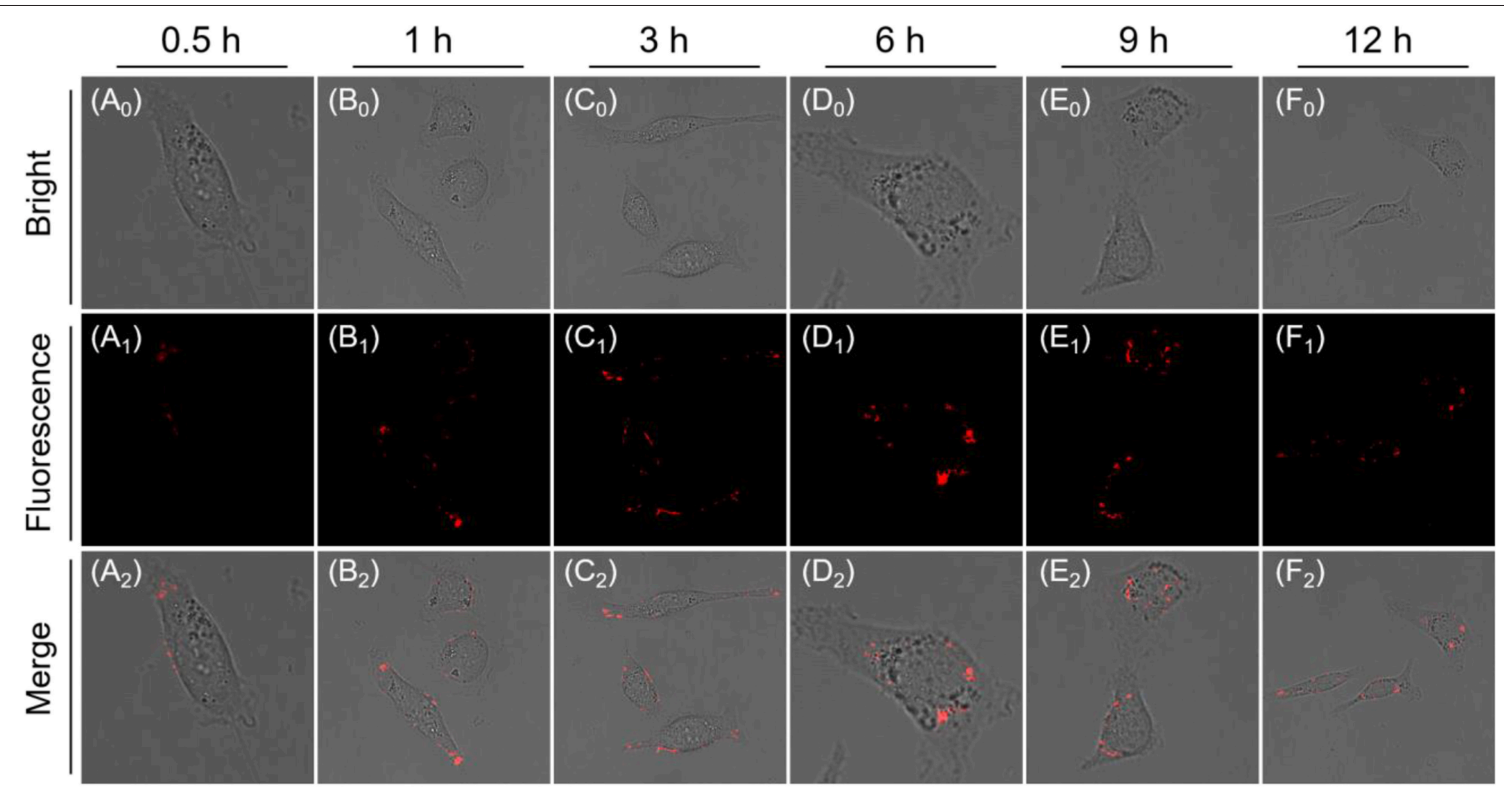

FIGURE 5 | Time-dependent CLSM images of SKOV-3 cells incubated with QM-HBT- $\beta$ gal (10 $\mu$ M) $\left(\mathbf{A}_{\mathbf{0}}-\mathbf{F}_{\mathbf{0}}\right.$ : Bright field, $\mathbf{A}_{\mathbf{1}}-\mathbf{F}_{\mathbf{1}}$ : Fluorescence channel) and $\left(\mathbf{A}_{\mathbf{2}}-\mathbf{F}_{\mathbf{2}}\right.$ : Merge channel). The window of fluorescence emission collection is $650-700 \mathrm{~nm}$ ( $\left.\lambda_{\mathrm{ex}}=460 \mathrm{~nm}\right)$. 
from AIEgen nanoaggregates largely overlaps with the green channel from Mito-Tracker Red and Golgi-Tracker Red, with Pearson's correlation coefficients of 0.8977 and 0.8522 (Table S1). These results indicate that enzyme-catalyzed AIEgen QM-HBT$\mathrm{OH}$ tends to mainly accumulate in the mitochondria and Golgi body.

Furthermore, long-term tracking of endogenous $\beta$ gal experiments also conducted in living cells. Indeed, its fluorescence intensity slowly increases and reaches a plateau at $3 \mathrm{~h}$, which does not change significantly over the next $3 \mathrm{~h}$ $(t=6 \mathrm{~h}$; Figure 5), suggesting the AIE-active NIR fluorescent signal is ascribed to nanoaggregate formation, which could amplify the fidelity signals because of emitting stronger during concentration enrichment of AIEgen nanoaggregates. Most importantly, AIEgen nanoaggregates do not easily leak out of cells during prolonged incubation, due to its lipophilicity of extending $\pi$-conjugated backbone. When the incubation time was increased to $12 \mathrm{~h}$, the intracellular fluorescence intensity was slightly attenuated and was fixed in the local region (Figure 5). In addition, we use the commercial nonin situ fluorescent probe (ICG) and the reported probe DCM- $\beta$ gal by introducing ACQ fluorophore dicyanomethylene$4 H$-pyran (DCM) as control compounds (Figures S6, S7), demonstrating the long-term tracking capability of NIR AIE-active QM-HBT- $\beta$ gal.

Altogether, all these experiment results verified that the AIE-active NIR probe QM-HBT- $\beta$ gal can overcome intracellular diffusion and attain high-fidelity enzyme information, enabling in situ and long-term tracking of $\beta$-gal in SKOV-3 cells.

\section{CONCLUSIONS}

In summary, we have developed an enzyme-responsive NIR AIE-active probe QM-HBT- $\beta$ gal for in situ and long-term tracking of endogenous $\beta$-gal activity, overcoming the dilemma of the requirement for released molecular fluorophores between diffusion-resistant and ACQ effect. Notably, QM-HBT- $\beta$ gal is

\section{REFERENCES}

Andreasson, J., and Pischel, U. (2018). Molecules for security measures: from keypad locks to advanced communication protocols. Chem. Soc. Rev. 47, 2266-2279. doi: 10.1039/c7cs00287d

Asanuma, D., Sakabe, M., Kamiya, M., Yamamoto, K., Hiratake, J., Ogawa, M., et al. (2015). Sensitive $\beta$-galactosidase-targeting fluorescence probe for visualizing small peritoneal metastatic tumours in vivo. Nat. Commun. 6:6463. doi: $10.1038 /$ ncomms 7463

Bhuniya, S., Maiti, S., Kim, E. J., Lee, H., Sessler, J. L., Hong, K. S., et al. (2014). An activatable theranostic for targeted cancer therapy and imaging. Angew. Chem. Int. Ed. 53, 4469-4474. doi: 10.1002/anie.201311133

Chen, L., Wu, D., Kim, J. M., and Yoon, J. (2017). An ESIPT-based fluorescence probe for colorimetric, ratiometric, and selective detection of phosgene in solutions and the gas phase. Anal. Chem. 89, 12596-12601. doi: 10.1021/acs.analchem.7b03988

Chen, X., Lee, D., Yu, S., Kim, G., Lee, S., Cho, Y., et al. (2017). In vivo near-infrared imaging and phototherapy of tumors using a cathepsin B-activated fluorescent probe. Biomaterials 122, 130-140. doi: 10.1016/j.biomaterials.2017.01.020 almost non-emissive in aqueous media, and upon the addition of $\beta$-gal, the masking groups at the hydroxyl moieties of QMHBT- $\beta$ gal were removed, thus recovering ESIPT and strong AIEactive NIR fluorescent signal in the aggregate states. Compared with other available $\beta$-gal probes, the AIE-active NIR probe QMHBT- $\beta$ gal not only provides localization signal of the $\beta$-gal at the reaction site but also avoids self-quenching when accumulated in cells, making obvious the advance in high-fidelity detection of endogenous enzyme activity. This study provides a promising strategy for the design of NIR AIE-active probes, paving a new pathway for in situ and long-term tracking of enzyme activity in preclinical applications.

\section{AUTHOR CONTRIBUTIONS}

WF and CY contributed equally. WF and CY was responsible for performing the experiments and writing manuscript. YZ and YM were responsible for providing cells. W-HZ were responsible for discussing experimental results. ZG was responsible for designing experiments and revising the paper.

\section{FUNDING}

This work was supported by NSFC/China (21788102, 21622602, 21636002, and 81522045), the National Key Research and Development Program (2017YFC0906902 and 2016YFA0200300), the Shanghai Municipal Science and Technology Major Project (grant no. 2018SHZDZX03), the Shuguang Program of Shanghai Education Development Foundation and Shanghai Municipal Education Commission (18SG27), and the Scientific Committee of Shanghai (15XD1501400).

\section{SUPPLEMENTARY MATERIAL}

The Supplementary Material for this article can be found online at: https://www.frontiersin.org/articles/10.3389/fchem. 2019.00291/full\#supplementary-material

Chen, Y. H., Wei, T. W., Zhang, Z. J., Chen, T. T., Li, J., Qiang, J., et al. (2017). A benzothiazole-based fluorescent probe for ratiometric detection of $\mathrm{Al}^{3+}$ in aqueous medium and living cells. Ind. Eng. Chem. Res. 56, 12267-12275. doi: 10.1021/acs.iecr.7b02979

Chevalier, A., Zhang, Y., Khdour, O. M., Kaye, J. B., and Hecht, S. M. (2016). Mitochondrial nitroreductase activity enables selective imaging and therapeutic targeting. J. Am. Chem. Soc. 138, 12009-12012. doi: 10.1021/jacs. 6 b06229

Cui, L., Baek, Y., Lee, S., Kwon, N., and Yoon, J. (2016). An AIE and ESIPT based kinetically resolved fluorescent probe for biothiols. J. Mater. Chem. C 4, 2909-2914. doi: 10.1039/c5tc03272e

Dimri, G. P., Lee, X., Basile, G., Acosta, M., Scott, G., Roskelley, C., et al. (1995). A biomarker that identifies senescent human cells in culture and in aging skin in vivo. Proc. Natl. Acad. Sci. U.S.A. 92, 9363-9367.

Feng, G., and Liu, B. (2018). Aggregation-induced emission (AIE) dots: emerging theranostic nanolights. Acc. Chem. Res. 51, 1404-1414. doi: 10.1021/acs.accounts.8b00060

Gu, K., Xu, Y., Li, H., Guo, Z., Zhu, S., Zhu, S., et al. (2016). Real-time tracking and in vivo visualization of $\beta$-galactosidase activity in colorectal tumor with a 
ratiometric near-infrared fluorescent probe. J. Am. Chem. Soc. 138, 5334-5340. doi: 10.1021/jacs.6b01705

Guo, Z., Park, S., Yoon, J., and Shin, I. (2014). Recent progress in the development of near-infrared fluorescent probes for bioimaging applications. Chem. Soc. Rev. 43, 16-29. doi: 10.1039/c3cs60271k

Guo, Z. Q., Shao, A. D., and Zhu, W. H. (2016). Long wavelength AIEgen of quinoline-malononitrile. J. Mater. Chem. C 4, 2640-2646. doi: $10.1039 / \mathrm{c} 5 \mathrm{tc0} 3369 \mathrm{a}$

Hu, Q., Gao, M., Feng, G., and Liu, B. (2014). Mitochondria-targeted cancer therapy using a light-up probe with aggregation-inducedemission characteristics. Angew. Chem. Int. Ed. 53, 14225-14229. doi: 10.1002/anie.201408897

Kamiya, M., Asanuma, D., Kuranaga, E., Takeishi, A., Sakabe, M., Miura, M., et al. (2011). $\beta$-Galactosidase fluorescence probe with improved cellular accumulation based on a spirocyclized rhodol scaffold. J. Am. Chem. Soc. 133, 12960-12963. doi: 10.1021/ja204781t

Kwok, R. T., Leung, C. W., Lam, J. W., and Tang, B. Z. (2015). Biosensing by luminogens with aggregation-induced emission characteristics. Chem. Soc. Rev. 44, 4228-4238. doi: 10.1039/c4cs00325j

Kwon, J. E., and Park, S. Y. (2011). Advanced organic optoelectronic materials: harnessing excited-state intramolecular proton transfer (ESIPT) process. Adv. Mater. 23, 3615-3642. doi: 10.1002/adma.201102046

Leung, C. W., Hong, Y., Chen, S., Zhao, E., Lam, J. W., and Tang, B. Z. (2013). A photostable AIE luminogen for specific mitochondrial imaging and tracking. J. Am. Chem. Soc. 135, 62-65. doi: 10.1021/ja310324q

Li, L., Zhang, C. W., Chen, G. Y., Zhu, B., Chai, C., Xu, Q. H., et al. (2014). A sensitive two-photon probe to selectively detect monoamine oxidase B activity in Parkinson's disease models. Nat. Commun. 5:3276. doi: $10.1038 /$ ncomms4276

Li, X., Gao, X., Shi, W., and Ma, H. (2014). Design strategies for water-soluble small molecular chromogenic and fluorogenic probes. Chem. Rev. 114, 590-659. doi: $10.1021 / \mathrm{cr} 300508 \mathrm{p}$

Li, X., Kwon, N., Guo, T., Liu, Z., and Yoon, J. (2018). Innovative strategies for hypoxic-tumor photodynamic therapy. Angew. Chem. Int. Ed. 57, 11522-11531. doi: 10.1002/anie.201805138

Li, Y., Sun, Y., Li, J., Su, Q., Yuan, W., Dai, Y., et al. (2015). Ultrasensitive nearinfrared fluorescence-enhanced probe for in vivo nitroreductase imaging. J. Am. Chem. Soc. 137, 6407-6416. doi: 10.1021/jacs.5b04097

Lim, S. Y., Hong, K. H., Kim, D. I., Kwon, H., and Kim, H. J. (2014). Tunable heptamethine-azo dye conjugate as an NIR fluorescent probe for the selective detection of mitochondrial glutathione over cysteine and homocysteine. J. Am. Chem. Soc. 136, 7018-7025. doi: 10.1021/ja500962u

Liu, H. W., Li, K., Hu, X. X., Zhu, L., Rong, Q., Liu, Y., et al. (2017). In situ localization of enzyme activity in live cells by a molecular probe releasing a precipitating fluorochrome. Angew. Chem. Int. Ed. 56, 11788-11792. doi: 10.1002/anie.201705747

Liu, L., Zhang, F., Xu, B., and Tian, W. (2017). Silica nanoparticles based on an AIE-active molecule for ratiometric detection of RNS in vitro. J. Mater. Chem. B 5, 9197-9203. doi: 10.1039/c7tb02734f

Liu, Z., Zhou, X., Miao, Y., Hu, Y., Kwon, N., Wu, X., et al. (2017). A reversible fluorescent probe for real-time quantitative monitoring of cellular glutathione. Angew. Chem. Int. Ed. 56, 5812-5816. doi: 10.1002/anie.2017 02114

Makukhin, N., Tretyachenko, V., Moskovitz, J., and Misek, J. (2016). A ratiometric fluorescent probe for imaging of the activity of methionine sulfoxide reductase A in cells. Angew. Chem. Int. Ed. 55, 12727-12730. doi: 10.1002/anie.201 605833

Mei, J., Leung, N. L., Kwok, R. T., Lam, J. W., and Tang, B. Z. (2015). Aggregation-induced emission: together we shine, united we soar! Chem. Rev. 115, 11718-11940. doi: 10.1021/acs.chemrev.5b00263

Nicol, A., Kwok, R. T. K., Chen, C., Zhao, W., Chen, M., Qu, J., et al. (2017). Ultrafast delivery of aggregation-induced emission nanoparticles and pure organic phosphorescent nanocrystals by saponin encapsulation. J. Am. Chem. Soc. 139, 14792-14799. doi: 10.1021/jacs.7b08710

Peng, L., Gao, M., Cai, X., Zhang, R., Li, K., Feng, G., et al. (2015). A fluorescent light-up probe based on AIE and ESIPT processes for $\beta$-galactosidase activity detection and visualization in living cells. J. Mater. Chem. B 3, 9168-9172. doi: $10.1039 / \mathrm{c} 5$ tb01938a
Portaccio, M., Stellato, S., Rossi, S., Bencivenga, U., Mohy Eldin, M. S., Gaeta, F. S., et al. (1998). Galactose competitive inhibition of $\beta$-galactosidase (Aspergillus oryzae) immobilized on chitosan and nylon supports. Enzyme Microb. Technol. 23, 101-106.

Qi, Y., Huang, Y., Li, B., Zeng, F., and Wu, S. (2018). Real-time monitoring of endogenous cysteine levels in vivo by near-infrared turn-on fluorescent probe with large stokes shift. Anal. Chem. 90, 1014-1020. doi: 10.1021/acs.analchem.7b04407

Qin, W., Ding, D., Liu, J., Yuan, W. Z., Hu, Y., Liu, B., et al. (2012). Biocompatible nanoparticles with aggregation-induced emission characteristics as far$\mathrm{red} /$ near-infrared fluorescent bioprobes for in vitro and in vivo imaging applications. Adv. Funct. Mater. 22, 771-779. doi: 10.1002/adfm.2011 02191

Sedgwick, A. C., Dou, W. T., Jiao, J. B., Wu, L., Williams, G. T., Jenkins, A. T. A., et al. (2018a). An ESIPT probe for the ratiometric imaging of peroxynitrite facilitated by binding to $\beta$-aggregates. J. Am. Chem. Soc. 140, 14267-14271. doi: $10.1021 /$ jacs.8b08457

Sedgwick, A. C., Wu, L., Han, H. H., Bull, S. D., He, X. P., James, T. D., et al. (2018b). Excited-state intramolecular proton-transfer (ESIPT) based fluorescence sensors and imaging agents. Chem. Soc. Rev. 47, 8842-8880. doi: $10.1039 / \mathrm{c} 8 \mathrm{cs} 00185 \mathrm{e}$

Shao, A., Xie, Y., Zhu, S., Guo, Z., Zhu, S., Guo, J., et al. (2015). Far-red and near-IR AIE-active fluorescent organic nanoprobes with enhanced tumortargeting efficacy: shape-specific effects. Angew. Chem. Int. Ed. 54, 7275-7280. doi: 10.1002/anie. 201501478

Shao, A. D., Guo, Z. Q., Zhu, S. J., Zhu, S. Q., Shi, P., Tian, H., et al. (2014). Insight into aggregation-induced emission characteristics of red-emissive quinolinemalononitrile by cell tracking and real-time trypsin detection. Chem. Sci. 5, 1383-1389. doi: 10.1039/c3sc52783b

Shi, C., Guo, Z., Yan, Y., Zhu, S., Xie, Y., Zhao, Y. S., et al. (2013). Selfassembly solid-state enhanced red emission of quinolinemalononitrile: optical waveguides and stimuli response. ACS Appl. Mater. Interfaces 5, 192-198. doi: 10.1021/am302466m

Shi, X., Yu, C. Y. Y., Su, H., Kwok, R. T. K., Jiang, M., He, Z., et al. (2017). A red-emissive antibody-AIEgen conjugate for turn-on and wash-free imaging of specific cancer cells. Chem. Sci. 8, 7014-7024. doi: 10.1039/c7sc01054k

Spergel, D. J., Krüth, U., Shimshek, D. R., Sprengel, R., and Seeburg, P. H. (2001). Using reporter genes to label selected neuronal populations in transgenic mice for gene promoter, anatomical, and physiological studies. Prog. Neurobiol. 63, 673-686. doi: 10.1016/s0301-0082(00)00038-1

Sun, W., Guo, S., Hu, C., Fan, J., and Peng, X. (2016). Recent development of chemosensors based on cyanine platforms. Chem. Rev. 116, 7768-7817. doi: 10.1021/acs.chemrev.6b00001

Sun, X., Xu, Q., Kim, G., Flower, S. E., Lowe, J. P., Yoon, J., et al. (2014). A water-soluble boronate-based fluorescent probe for the selective detection of peroxynitrite and imaging in living cells. Chem. Sci. 5, 3368-3373. doi: $10.1039 / \mathrm{c} 4 \mathrm{sc} 01417 \mathrm{k}$

Taylor, A., Wilson, K. M., Murray, P., Fernig, D. G., and Levy, R. (2012). Long-term tracking of cells using inorganic nanoparticles as contrast agents: are we there yet? Chem. Soc. Rev. 41, 2707-2717. doi: 10.1039/c2cs35031a

Thorn-Seshold, O., Vargas-Sanchez, M., McKeon, S., and Hasserodt, J. (2012). A robust, high-sensitivity stealth probe for peptidases. Chem. Commun. 48, 6253-6255. doi: 10.1039/c2cc32227g

Wang, F., Zhu, Y., Zhou, L., Pan, L., Cui, Z., Fei, Q., et al. (2015). Fluorescent in situ targeting probes for rapid imaging of ovarian-cancerspecific gamma-glutamyltranspeptidase. Angew. Chem. Int. Ed. 54, 7349-7353. doi: 10.1002/anie.201502899

Wang, H., Ma, K., Xu, B., and Tian, W. (2016). Tunable supramolecular interactions of aggregation-induced emission probe and graphene oxide with biomolecules: an approach toward ultrasensitive label-free and "turn-on" DNA sensing. Small 12, 6613-6622. doi: 10.1002/smll.201601544

Wang, M., Xu, Y., Liu, Y., Gu, K., Tan, J., Shi, P., et al. (2018). Morphology tuning of aggregation-induced emission probes by flash nanoprecipitation: shape and size effects on in vivo imaging. ACS Appl. Mater. Interfaces 10, 25186-25193. doi: 10.1021/acsami.8b08159

Wang, Y.-L., Fan, C., Xin, B., Zhang, J.-P., Luo, T., Chen, Z.-Q., et al. (2018). AIEbased super-resolution imaging probes for $\beta$-amyloid plaques in mouse brains. Mater. Chem. Front. 2, 1554-1562. doi: 10.1039/c8qm00209f 
Wang, Z., Chen, S., Lam, J. W., Qin, W., Kwok, R. T., Xie, N., et al. (2013). Longterm fluorescent cellular tracing by the aggregates of AIE bioconjugates. J. Am. Chem. Soc. 135, 8238-8245. doi: 10.1021/ja312581r

Wu, D., Sedgwick, A. C., Gunnlaugsson, T., Akkaya, E. U., Yoon, J., and James, T. D. (2017). Fluorescent chemosensors: the past, present and future. Chem. Soc. Rev. 46, 7105-7123. doi: 10.1039/c7cs00240h

Wu, X., Li, L., Shi, W., Gong, Q., and Ma, H. (2016). Near-infrared fluorescent probe with new recognition moiety for specific detection of tyrosinase activity: design, synthesis, and application in living cells and zebrafish. Angew. Chem. Int. Ed. 55, 14728-14732. doi: 10.1002/anie.201609895

Wu, X., Sun, X., Guo, Z., Tang, J., Shen, Y., James, T. D., et al. (2014). In vivo and in situ tracking cancer chemotherapy by highly photostable NIR fluorescent theranostic prodrug. J. Am. Chem. Soc. 136, 3579-3588. doi: 10.1021/ja412380j

Xie, S., Wong, A. Y. H., Kwok, R. T. K., Li, Y., Su, H., Lam, J. W. Y., et al. (2018). Fluorogenic $\mathrm{Ag}(+)$-tetrazolate aggregation enables efficient fluorescent biological silver staining. Angew. Chem. Int. Ed. 57, 5750-5753. doi: 10.1002/anie.201801653

Xu, K., Luan, D., Wang, X., Hu, B., Liu, X., Kong, F., et al. (2016). An ultrasensitive cyclization-based fluorescent probe for imaging native $\mathrm{HOBr}$ in live cells and zebrafish. Angew. Chem. Int. Ed. 55, 12751-12754. doi: 10.1002/anie.201606285

Xu, Q., Heo, C. H., Kim, G., Lee, H. W., Kim, H. M., and Yoon, J. (2015). Development of imidazoline-2-thiones based two-photon fluorescence probes for imaging hypochlorite generation in a co-culture system. Angew. Chem. Int. Ed. 54, 4890-4894. doi: 10.1002/anie.201500537

Xu, Q., Heo, C. H., Kim, J. A., Lee, H. S., Hu, Y., Kim, D., et al. (2016). A selective imidazoline-2-thione-bearing two-photon fluorescent probe for hypochlorous acid in mitochondria. Anal. Chem. 88, 6615-6620. doi: 10.1021/acs.analchem.6b01738

Yan, C., Guo, Z., Liu, Y., Shi, P., Tian, H., and Zhu, W. H. (2018a). A sequence-activated AND logic dual-channel fluorescent probe for tracking programmable drug release. Chem. Sci. 9, 6176-6182. doi: 10.1039/c8sc02079e

Yan, C., Guo, Z., Shen, Y., Chen, Y., Tian, H., and Zhu, W. H. (2018b). Molecularly precise self-assembly of theranostic nanoprobes within a single-molecular framework for in vivo tracking of tumor-specific chemotherapy. Chem. Sci. 9, 4959-4969. doi: 10.1039/c8sc01069b

Yan, J., Lee, S., Zhang, A., and Yoon, J. (2018c). Self-immolative colorimetric, fluorescent and chemiluminescent chemosensors. Chem. Soc. Rev. 47, 6900-6916. doi: 10.1039/c7cs00841d

Yan, L., Zhang, Y., Xu, B., and Tian, W. (2016). Fluorescent nanoparticles based on AIE fluorogens for bioimaging. Nanoscale 8, 2471-2487. doi: $10.1039 / \mathrm{c} 5 \mathrm{nr} 05051 \mathrm{k}$

Yang, J., Ren, Z., Xie, Z., Liu, Y., Wang, C., Xie, Y., et al. (2017). AIEgen with fluorescence-phosphorescence dual mechanoluminescence at room temperature. Angew. Chem. Int. Ed. 56, 880-884. doi: 10.1002/anie.201610453

Yang, Y., Zhao, Q., Feng, W., and Li, F. (2013). Luminescent chemodosimeters for bioimaging. Chem. Rev. 113, 192-270. doi: 10.1021/cr2004103
Yin, J., Kwon, Y., Kim, D., Lee, D., Kim, G., Hu, Y., et al. (2014). Cyaninebased fluorescent probe for highly selective detection of glutathione in cell cultures and live mouse tissues. J. Am. Chem. Soc. 136, 5351-5358. doi: $10.1021 / \mathrm{ja} 412628 \mathrm{z}$

Yuan, Y., Zhang, C. J., Xu, S., and Liu, B. (2016). A self-reporting AIE probe with a built-in singlet oxygen sensor for targeted photodynamic ablation of cancer cells. Chem. Sci. 7, 1862-1866. doi: 10.1039/c5sc03583j

Zhang, F., Di, Y., Li, Y., Qi, Q., Qian, J., Fu, X., et al. (2017). Highly efficient far red/near-infrared fluorophores with aggregation-induced emission for bioimaging. Dyes Pigm. 142, 491-498. doi: 10.1016/j.dyepig.2017. 04.004

Zhang, J., Chai, X., He, X. P., Kim, H. J., Yoon, J., and Tian, H. (2018). Fluorogenic probes for disease-relevant enzymes. Chem. Soc. Rev. 48, 683-722. doi: $10.1039 / \mathrm{c} 7 \mathrm{cs} 00907 \mathrm{k}$

Zhang, L., Duan, D., Liu, Y., Ge, C., Cui, X., Sun, J., et al. (2014). Highly selective off-on fluorescent probe for imaging thioredoxin reductase in living cells. J. Am. Chem. Soc. 136, 226-233. doi: 10.1021/ja408792k

Zhang, P., Nie, X., Gao, M., Zeng, F., Qin, A., Wu, S., et al. (2017). A highly selective fluorescent nanoprobe based on AIE and ESIPT for imaging hydrogen sulfide in live cells and zebrafish. Mater. Chem. Front. 1, 838-845. doi: $10.1039 / \mathrm{c} 6 \mathrm{qm} 00223 \mathrm{~d}$

Zhou, J., Shi, W., Li, L., Gong, Q., Wu, X., Li, X., et al. (2016). Detection of misdistribution of tyrosinase from melanosomes to lysosomes and its upregulation under psoralen/ultraviolet a with a melanosometargeting tyrosinase fluorescent probe. Anal. Chem. 88, 4557-4564. doi: 10.1021/acs.analchem.6b00742

Zhou, L., Zhang, X., Lv, Y., Yang, C., Lu, D., Wu, Y., et al. (2015). Localizable and photoactivatable fluorophore for spatiotemporal two-photon bioimaging. Anal. Chem. 87, 5626-5631. doi: 10.1021/acs.analchem.5b00691

Zhou, P., and Han, K. (2018). Unraveling the detailed mechanism of excited-state proton transfer. Acc. Chem. Res. 51, 1681-1690. doi: 10.1021/acs.accounts.8b00172

Zhu, H., Fan, J., Du, J., and Peng, X. (2016). Fluorescent probes for sensing and imaging within specific cellular organelles. Acc. Chem. Res. 49, 2115-2126. doi: 10.1021/acs.accounts.6b00292

Conflict of Interest Statement: The authors declare that the research was conducted in the absence of any commercial or financial relationships that could be construed as a potential conflict of interest.

Copyright (C) $2019 \mathrm{Fu}$, Yan, Zhang, Ma, Guo and Zhu. This is an open-access article distributed under the terms of the Creative Commons Attribution License (CC BY). The use, distribution or reproduction in other forums is permitted, provided the original author(s) and the copyright owner(s) are credited and that the original publication in this journal is cited, in accordance with accepted academic practice. No use, distribution or reproduction is permitted which does not comply with these terms. 